J. Asiati. Soc. Bangladesh, Sci. 44(4): 173-183, December 2018

\title{
IMPACTS OF RICE HULL AND PISTIA ON THE VEGETATIVE GROWTH OF RICE AND PHYSICO-CHEMICAL PROPERTIES OF SALINE SOIL UNDER VARIABLE MOISTURES
}

\author{
MOHAMMED SADID HOSSAIN ${ }^{1}$, MD. HARUNOR RASHID KHAN, \\ SUMA AKTER, MITHUN KUMAR SAHA AND FARIHA FARZANA \\ Department of Soil, Water and Environment, University of Dhaka, \\ Dhaka-1000, Bangladesh
}

\begin{abstract}
A pot experiment was conducted using BRRI Hybrid Dhan-6 variety of rice at the premises of the Department of Soil, Water and Environment, University of Dhaka, Bangladesh to evaluate the capabilities of rice hull (RH: 0, 2, $4 \mathrm{t} \mathrm{ha}^{-1}$ ) and pistia (PT: 0, $400,800 \mathrm{~kg} \mathrm{ha}^{-1}$ ) for the improvement of growth performances of rice grown under field moist (FM: 70\% moisture) and $2-5 \mathrm{~cm}$ standing water (SW) conditions in saline soil. Among the vegetative growth, the plant heights, number of productive tillers, fresh shoot and shoot dry matter weights were found to be increased significantly $(\mathrm{p} \leq 0.05)$ with the increased rates of rice hull and pistia treatments, and the increments were more striking by their combinations in most of the cases under both FM and SW conditions. The tallest plant heights (112 cm in FM and $120 \mathrm{~cm}$ in SW) and the maximum number of productive tillers (13 in FM and 16 in $\mathrm{SW}$ ) were recorded at maturity stage of rice in the $\mathrm{T}_{8}$ $\left(\mathrm{RH}_{4} \mathrm{PT}_{8}\right)$ treatment where rice hull and pistia were applied at the highest $\left(\mathrm{RH}: 4 \mathrm{t} \mathrm{ha}^{-1}\right.$, PT: $800 \mathrm{~kg} \mathrm{ha}^{-1}$ ) dosages. Based on superiority in both the plant heights and number of tillers, the amendments can be arranged in the sequence of $T_{8}>T_{7}>T_{6}>T_{5}>T_{2}>T_{3}>T_{4}>$ $\mathrm{T}_{0}>\mathrm{T}_{1}$. The analysis of variance on these data indicated that in the standing water condition, fresh shoot and shoot dry matter weights of rice plants were found to be increased significantly $(\mathrm{p} \leq 0.05)$ by the application of the higher rates of the treatments and their combinations. Thus, the application of indigenous organic amendments such as, rice hull and pistia showed significant contribution for the growth performances of rice under variable moistures but further researches are needed under variable soil and climatic conditions to ensure food security under saline soil.
\end{abstract}

Key words: Moistures, Plant height, Pistia, Rice hull, Shoot yield, Tiller production

\section{Introduction}

Bangladesh has $710 \mathrm{~km}$ long coastline running parallel to the Bay of Bengal. The economy of Bangladesh largely depends on agriculture and rice is the staple food of the country. More than $30 \%$ of the cultivable land in Bangladesh is in the coastal area. Out of 2.86 million hectares of coastal and off-shore lands, about 1.056 million ha of arable lands are affected by varying degrees of salinity (SRDI 2010). Farmers mostly cultivate

*Author for correspondence: E-mail: hossain.sadid90@gmail.com 
low yielding, traditional rice varieties during wet season. Most of the land remains fallow in the dry season (January - May) because of soil salinity, lack of good quality irrigation water and slow draining condition (SRDI 2010). Crop production of the salt affected areas in the coastal regions differs considerably from non-saline areas. Because of salinity, special environmental and hydrological situation exists, that restrict the normal crop production throughout the year. In the recent past, with the changing degree of salinity of some areas due to further intrusion of saline water, normal crop production becomes very risky. Crop yields, cropping intensity, production levels and people's quality of livelihood are much lower than that of other parts of the country (SRDI 2010).

The problem of salt-affected soils has gained ever-increasing importance in science, technology, ecology and society during the last few decades. It has been evidenced that the coastal salinity is increasing in the coastal zone due to sea level rise, reduction of fresh water flow in the southern rivers and also due to entrainment of sea water with recurrent storm surges caused by the increasing frequency of tropical cyclones of higher intensity (Quadir and Iqbal 2008). Salt affected coastal areas in Bangladesh mainly include the problematic saline $(>20 \%)$ and acid sulfate $(>3 \%)$ soils, which occupied $>23 \%$ of the cultivable lands (Khan et al. 2016). They also added that these soils displayed high agricultural potentials when they were to be reclaimed by appropriate methods. Because of the highly saline ( $2 \%$ salts) sea or river waters and ground waters, application of salt free water is quite impossible.

The agro-climatic conditions of the country are suitable for growing rice round the year. However, the country's average rice yield is much lower (2.97 t/ha, BBS 2017) than those of China and Japan (6 - $6.5 \mathrm{t} / \mathrm{ha}$, BRRI 2015). The BBS also reported that rice is the staple food for about 160 million people of the country. The population growth rate is 2 million per year, and if the population increases at this rate, the total population will reach 238 million by 2050 (BBS 2017). An increase in total rice production is required to feed this ever-increasing population. Rice has been reported as salt susceptible in both seedling and reproductive stages leading to a reduction of more than $50 \%$ in yield when exposed to $6.65 \mathrm{dS} \mathrm{m}^{-1} \mathrm{ECe}$ (Reddy et al. 2017). So rice production is drastically reduced due to salinity and low fertility of coastal soils.

As an organic material, there is a significant quantity of rice hull at farmers' level. It improves water holding capacity of soil. It also increases organic matter content of the soil and subsequently increase crop yield (Begum and Khan 2013). Prakash et al. (2002) emphasized that rice hull improved soil silicon status and sustained better rice production. Another organic amendment, Pistia stratiotes (water lettuce) is the world's 
most productive freshwater aquatic plant and considered an invasive species. On dry matter basis, it contained $49.3 \%$ total C, 2.95\% N, 0.57\% P, 4\% K, 103.6 ppm Zn, 19.03 ppm B in leaf and $46.4 \%$ total C, 2.45\% N, 0.49\% P, 1.2\% K, 264.8 ppm Zn, 17.08 ppm B in root (Kanwal et al. 2011). They also added that it contained $94 \%$ moisture. In saline soils, water movement is one of the major problems due to the adverse effects of salinity on soil physical properties which may be improved by the indigenous organic amendments like rice hull and pistia. Hence, the salinity affected coastal areas could be reclaimed by different management strategies, such as improved hydrology, application of agricultural amendments, adaptation and screen out of different salt tolerant crops. These multi-approached works will not only be helpful for understanding the real nature of the problem but also assist proper reclamation, improvement of soil health resulting in food security under variable climates and economic use of saline soils which could be a new resource for the society/country. Against this background, this present research was undertaken to evaluate the effects of rice hull and pistia on the vegetative growth of rice and physico-chemical properties of saline soil under variable moisture levels.

\section{Materials and Methods}

A pot experiment was carried out using BRRI Hybrid Dhan-6 variety of rice in the premises of Department of Soil, Water and Environment, University of Dhaka. The saline soil used in the experiment was collected from Musulliabad, Kalapara, Patuakhali during April to July, 2017. Indigenous organic amendments such as Rice Hull (RH) and Pistia (PT) were used for the studied soil. Five kilograms of air dried, ground and $5 \mathrm{~mm}$ sieved composite soil was filled in each earthen pots (size: $8 \mathrm{~kg}$ ). The experiment was designed following completely randomized design with the application of Rice Hull (having 3 doses 0, 2, 4 t/ha) and Pistia (having 3 doses $0,400,800 \mathrm{~kg} / \mathrm{ha}$ ) having 3 replications under 2 sets of moisture levels (Field moist: FM and $2-5 \mathrm{~cm}$ standing water conditions: $\mathrm{SW})$. The treatments were $\mathrm{T}_{0}=($ Control $) \mathrm{RH}_{0} \mathrm{PT}_{0}, \mathrm{~T}_{1}=\mathrm{RH}_{0} \mathrm{PT}_{4}, \mathrm{~T}_{2}=\mathrm{RH}_{0} \mathrm{PT}_{8}, \mathrm{~T}_{3}=$ $\mathrm{RH}_{2} \mathrm{PT}_{0}, \mathrm{~T}_{4}=\mathrm{RH}_{2} \mathrm{PT}_{4}, \mathrm{~T}_{5}=\mathrm{RH}_{2} \mathrm{PT}_{8}, \mathrm{~T}_{6}=\mathrm{RH}_{4} \mathrm{PT}_{0}, \mathrm{~T}_{7}=\mathrm{RH}_{4} \mathrm{PT}_{4}, \mathrm{~T}_{8}=\mathrm{RH}_{4} \mathrm{PT}_{8}$. Basal doses of N, P and $\mathrm{K}$ were applied at the rate of 120,60 and $80 \mathrm{~kg} / \mathrm{ha}$ from urea, TSP and MoP fertilizers, respectively. The whole TSP, MoP and half of the urea were applied during soil preparation by thorough mixing of the fertilizers with soils. The remaining urea was top dressed in two splits, one at active tillering and another at panicle initiation stage.

Seedling was collected from Bangladesh Rice Research Institute. Thirty-day-old seedlings of BRRI Hybrid Dhan-6 were transplanted at the rate of 3 plants per hill and 3 hills per pot. For the proper establishment of the rice seedlings, all pots were irrigated 
with tap water for two weeks after transplantation and then the moisture levels were maintained by the irrigation from the same tap water. In the case of moist condition: 70\% water content seemed to be optimum for the survival of rice plant and did not allow standing water. But in the case of saturated condition: more than $100 \%$ water, i.e. 2 - 5 $\mathrm{cm}$ standing water was maintained during irrigation and kept the field always wet throughout the growing period. Intercultural operations were practiced throughout the experiment when necessary. The physico-chemical characteristics of initial soil were determined by following standard methods (Table 1). The bulk soil samples were airdried, crushed and passed through $2 \mathrm{~mm}$ seive before analysis. After treatment with $1 \mathrm{M}$ $\mathrm{CH}_{3} \mathrm{COONH}_{4}$ (pH 5.0) and with $30 \% \mathrm{H}_{2} \mathrm{O}_{2}$ to remove free salts and organic matter respectively, particle size distribution of the initial soil was determined by the Hydrometer method (Piper 1966).

Table 1. Physico-chemical characteristics of initial saline soil $(1-15 \mathrm{~cm})$ on oven dry basis.

\begin{tabular}{|c|c|c|c|}
\hline Properties & Values & Properties & Values \\
\hline $\begin{array}{l}\text { Textural class } \\
\text { (Hydrometer) }\end{array}$ & $\begin{array}{l}\text { Silty clay } \\
\text { loam }\end{array}$ & $\begin{array}{l}\text { Exchangeable cations } \\
\text { (C mol/kg) }\end{array}$ & \\
\hline Soil pH (soil: water = $1: 2.5$ ) & 6.3 & $\mathrm{Na}^{+}$(Flame Photometer) & 4.02 \\
\hline $\mathrm{EC}($ soil $:$ water $=1: 5, \mathrm{dS} / \mathrm{m})$ & 4.17 & $\mathrm{~K}^{+}$(Flame Photometer) & 1.90 \\
\hline Organic carbon (g/kg, wet oxidation) & 14.3 & $\mathrm{Ca}^{2+}(\mathrm{AAS})$ & 2.90 \\
\hline Total N (Micro Kjeldahl, g/kg) & 1.4 & $\mathrm{Mg}^{2+}(\mathrm{AAS})$ & 2.50 \\
\hline $\mathrm{C} / \mathrm{N}$ ratio & 10.20 & $\begin{array}{l}\text { Water soluble ions } \\
(\mathrm{C} \mathrm{mol} / \mathrm{kg}) \text { : }\end{array}$ & \\
\hline Cation exchange capacity ( $\mathrm{C} \mathrm{mol} / \mathrm{kg}$ ) & 21.23 & $\mathrm{Cl}^{-}$ & 2.63 \\
\hline Available N (mg/kg, Micro Kjeldahl) & 42 & $\mathrm{SO}^{-2}$ & 1.75 \\
\hline Available S (mg/kg, Spectrophotometer) & 192 & Carbonate & Nil \\
\hline Available P (mg/kg, Spectrophotometer) & 14 & Bicarbonate & 0.98 \\
\hline Available K (mg/kg, Flame photometer) & 24.16 & Sodium adsorption ratio & 2.45 \\
\hline Base saturation percentage & 53.32 & $\begin{array}{l}\text { Exchangeable sodium } \\
\text { percentage }\end{array}$ & 20.92 \\
\hline
\end{tabular}

*AAS = Atomic Absorption Spectrophotometer.

Soil pH was measured at the soil-water ratio of $1: 2.5$ (Jackson 1973). The electrical conductivity was determined at a ratio soil : water $=1: 5$ (Richards 1954). Organic matter content was determined (Nelson and Sommers 1982) by wet combustion with $\mathrm{K}_{2} \mathrm{Cr}_{2} \mathrm{O}_{7}$. Available N (1.3 M KCl extraction, Jackson 1973), available $\mathrm{P}(0.5 \mathrm{M}$ $\mathrm{NaHCO}_{3}, \mathrm{pH} 8.5$ extraction, Olsen et al. 1954), available K (Pratt 1965) and available S 
$\left(\mathrm{BaCl}_{2}\right.$ turbidity, Sakai 1978$)$ were determined. Cation exchange capacity was determined by saturation with $1 \mathrm{M} \mathrm{CH}_{3} \mathrm{COONH}_{4}\left(\mathrm{pH}\right.$ 7.0), ethanol washing, $\mathrm{NH}_{4}{ }^{+}$displacement with acidified $10 \% \mathrm{NaCl}$, and subsequent analysis by steam (Kjeldhal method) distillation (Chapman 1965). Water soluble $\mathrm{SO}_{4}{ }^{-2}$ and $\mathrm{Cl}^{-}$(Jackson 1973), $\mathrm{HCO}_{3}{ }^{-}$and $\mathrm{CO}_{3}{ }^{-}$(USSLS 1954) contents were determined. Exchangeable $\mathrm{Na}^{+}, \mathrm{K}^{+}, \mathrm{Ca}^{2+}$ and $\mathrm{Mg}^{2+}$ were extracted with $1 \mathrm{M} \mathrm{CH}_{3} \mathrm{COONH}_{4}\left(\mathrm{pH}\right.$ 7.0) and determined by flame photometry $\left(\mathrm{Na}^{+}, \mathrm{K}^{+}\right)$and atomic absorption spectrometry $\left(\mathrm{Ca}^{+}, \mathrm{Mg}^{+}\right)$.

Plant samples were collected after harvesting the crop at maturity. The plants per pot were cut at the $1 \mathrm{~cm}$ above ground level and the $\mathrm{N}$ contents were analyzed by the $\mathrm{H}_{2} \mathrm{SO}_{4}$ digestion through the micro-Kjeldhal method (Jackson 1973) and $\mathrm{P}$ contents by spectrophotometry (Jackson 1973), K contents by Gallenkamp flame photometry (Black 1965). The analysis of variance (ANOVA) of the data and the test of significance of the different treatments' means were assessed by Tukey's range test at $5 \%$ level.

\section{Results and Discussion}

The plant height is one of the most indicative parameters and the response of the application of different organic amendments reflected quickly on this parameter. Moreover, it indicates the influence of various nutrients on plant metabolism. Analyses of the results demonstrate that the individual variables, such as, rice hull and pistia exerted significant $(\mathrm{p} \leq 0.05)$ effects on the growth of rice. Plant heights increased significantly $(\mathrm{p} \leq 0.05)$ with the increased rates of rice hull and pistia treatments and their combinations under both field moist (FM) and standing water (SW) conditions. The tallest plant heights $(112 \mathrm{~cm}$ in FM and $120 \mathrm{~cm}$ in SW) were recorded at maturity stage of rice in the $\mathrm{T}_{8}\left(\mathrm{RH}_{4} \mathrm{PT}_{8}\right)$ treatment where rice hull and pistia were applied at the highest dosages (Fig. 1). The lowest plant heights $(65 \mathrm{~cm}$ in FM and $70 \mathrm{~cm}$ in SW) were observed at maturity stage of plants in the control treatment $\left(\mathrm{T}_{0}=\mathrm{RH}_{0} \mathrm{PT}_{0}\right)$. Though the soil is different but almost similar results were reported by Kamara et al. (2015). They used rice straw as organic amendment and reported that rice plants grown on soils treated with rice straw were significantly $(\mathrm{p} \leq 0.05)$ taller than those grown on soils without treatment. Another study indicated that incorporation of rice straw into the soil combined with application of cattle manure gave the maximum plant height (Parham et al. 2002).

The number of productive tillers at maturity stage of rice was influenced by the different rates of rice hull and pistia and their combinations (Fig. 2). There was a positive significant $(\mathrm{p} \leq 0.05)$ increase in number of productive tillers with higher rates of organic amendments and their combinations under FM and SW conditions. The maximum 
number of productive tillers (13 in FM and 16 in SW) was recorded at maturity stage in the $\mathrm{T}_{8}\left(\mathrm{RH}_{4} \mathrm{PT}_{8}\right)$ treatment followed by the $\mathrm{T}_{7}\left(\mathrm{RH}_{4} \mathrm{PT}_{4}\right)$ treatment (Fig. 2). Based on superiority, in case of tiller production, amendments could be arranged in the following sequence of $T_{8}>T_{7}>T_{6}>T_{4}>T_{2}>T_{3}>T_{1}>T_{0}>T_{5}$. Tiller production was the lowest in the $\mathrm{T}_{5}\left(\mathrm{RH}_{2} \mathrm{PT}_{8}\right)$ treatment which was unexpected. This might be due to the attack of insects

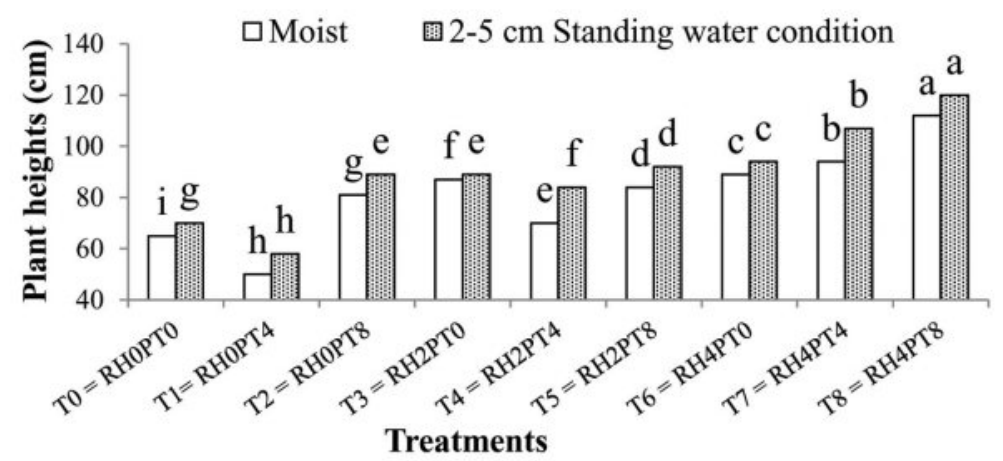

Fig. 1. Effects of rice hull and pistia on plant heights of rice (BRRI Hybrid Dhan-6) grown under field moist (70\% moisture) and $2-5 \mathrm{~cm}$ standing water conditions.

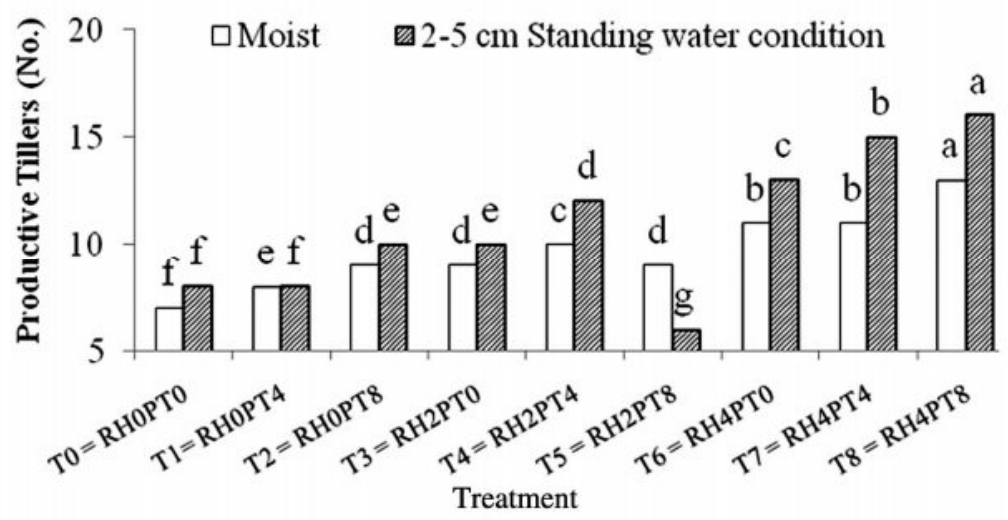

Fig. 2. Effects of rice hull and pistia on the number of productive tillers of rice (BRRI Hybrid Dhan-6) grown under field moist (70\% moisture) and $2-5 \mathrm{~cm}$ standing water conditions.

on rice plants. Almost similar observation was found from another study conducted in other coastal areas of Bangladesh (Kaniz and Khan 2013). They found that application of rice hull increased growth and yield contributing characters of BRRI Dhan 47. Though they have practiced for the higher rates and suggested to practice for the lower rates of 
treatments. So they concluded that the application of rice hull is effective in improving the adverse effect of salinity and growth performance of rice plant.

The fresh shoot and shoot dry matter weights of rice plants were found to be influenced by different rates of organic amendments (rice hull and pistia) and their combinations under both the field moist and $2-5 \mathrm{~cm}$ standing water conditions (Figs 3 and 4). The analysis of variance on these data indicated the fresh shoot and shoot dry matter weights increased significantly $(\mathrm{p} \leq 0.05)$ by the individual application of rice hull, pistia and their combinations at the higher rates. In moist condition, the maximum fresh shoot (32.4 g) and shoot dry matter weights $(18.4 \mathrm{~g})$

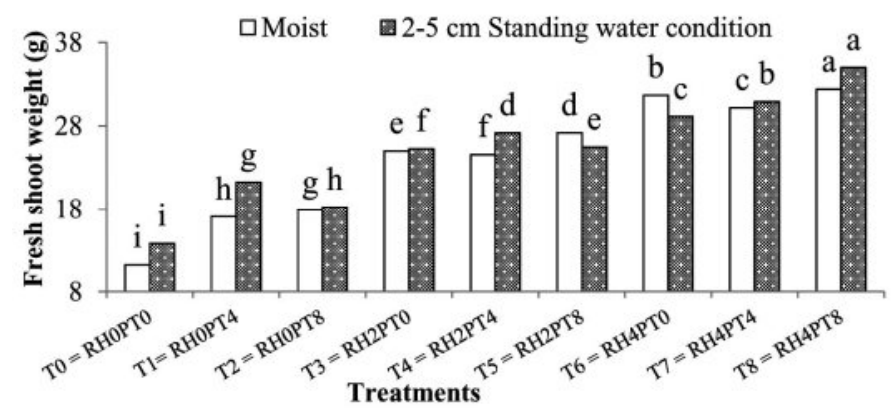

Fig. 3. Effects of rice hull and pistia on the fresh shoot weight (g) of rice (BRRI Hybrid Dhan-6) grown under field moist (70\% moisture) and $2-5 \mathrm{~cm}$ standing water conditions.

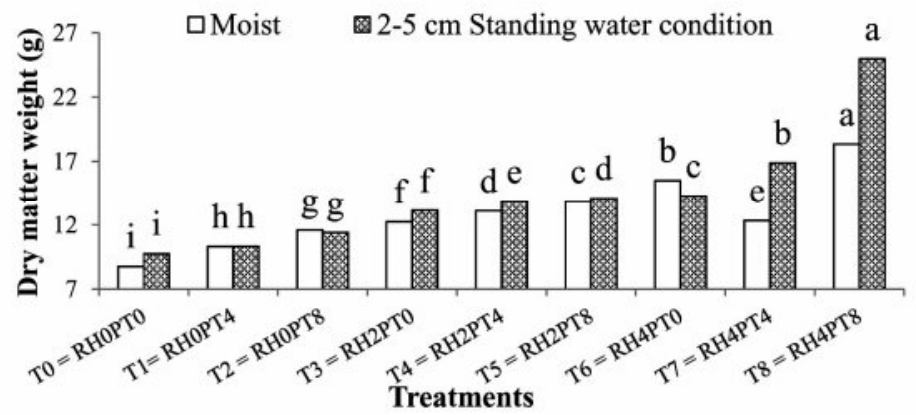

Fig. 4. Effects of rice hull and pistia on the shoot dry matter weight $(\mathrm{g})$ of rice (BRRI Hybrid Dhan-6) under field moist (70\% moisture) and $2-5 \mathrm{~cm}$ standing water conditions.

were recorded at maturity stage in the $\mathrm{T}_{8}\left(\mathrm{RH}_{4} \mathrm{PT}_{8}\right)$ treatment which received the highest rates of the combination of these treatments. The minimum fresh shoot $(11.25 \mathrm{~g})$ and shoot dry matter weights $(8.75 \mathrm{~g})$ were measured at maturity stage in the control 
condition where no treatment was applied. In the standing water condition, fresh shoot and shoot dry matter weights of rice plants were found to be increased significantly ( $\mathrm{p} \leq$ 0.05 ) by the application of the higher rates of treatments and their combination. In case of standing water condition, almost similar patterns of increase in fresh shoot and dry matter weights were found with the increased rates of amendments.

There were remarkable variations in $\mathrm{pH}$ of post harvest soils with the changes in the doses of organic amendments (rice hull and pistia) under both field moist and $2-5 \mathrm{~cm}$ standing water conditions (Fig. 5). The highest value of soil $\mathrm{pH}$ (7.4) was recorded in the treatment $\mathrm{T}_{6}\left(\mathrm{RH}_{4} \mathrm{PT}_{0}\right)$ in the field moist condition. In the standing water condition, the maximum value (7.3) of soil $\mathrm{pH}$ was measured in the $\mathrm{T}_{2}\left(\mathrm{RH}_{0} \mathrm{PT}_{8}\right)$ treatment. Though thesevalues did not comply with the best treatment regarding vegetative growth of rice,

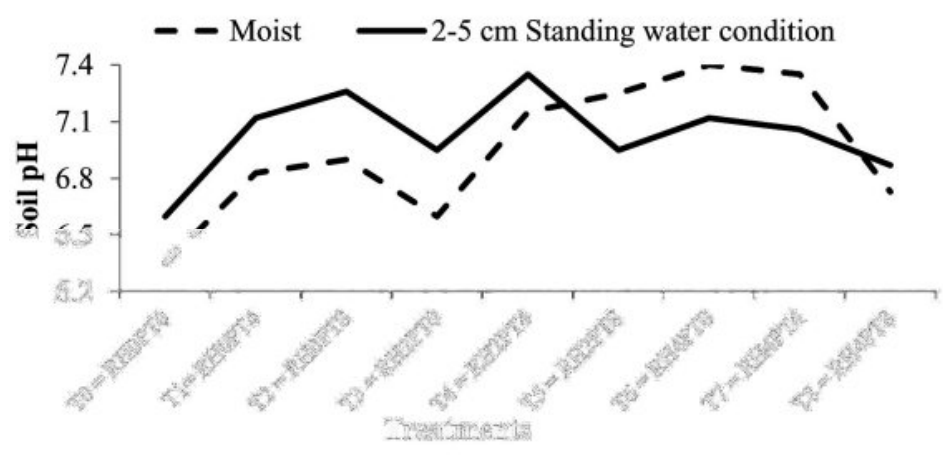

Fig. 5. Effects of rice hull and pistia on the $\mathrm{pH}$ of the post harvest soils under field moist (70\% moisture) and $2-5 \mathrm{~cm}$ standing water conditions during cultivations.

which might be attributed to the soil $\mathrm{pH}$ values $(7.3-7.4)$, which are not in the optimum range of soil $\mathrm{pH}(5.5-6.5)$ for rice production. The lowest value of soil $\mathrm{pH}$ was obtained from the control condition under both FM ( $\mathrm{pH} \mathrm{6.73)} \mathrm{and} \mathrm{SW} \mathrm{(pH} \mathrm{6.87)} \mathrm{conditions.} \mathrm{The}$ $\mathrm{pH}$ of the soils were found to be increased bythe individual lower doses of these treatments $\left(\mathrm{T}_{1}=\mathrm{RH}_{0} \mathrm{PT}_{4}, \mathrm{~T}_{2}=\mathrm{RH}_{0} \mathrm{PT}_{8}\right)$ and reached a peak value by the increased doses of these treatments $\left(\mathrm{T}_{4}=\mathrm{RH}_{2} \mathrm{PT}_{4}, \mathrm{~T}_{6}=\mathrm{RH}_{4} \mathrm{PT}_{0}\right)$ and then declined by the highest dose of treatment $\left(\mathrm{T}_{8}=\mathrm{RH}_{4} \mathrm{PT}_{8}\right)$. When the higher rates of organic amendments were applied, decomposition of orgnaic amendments might help in releasing oranic acids, which are responsible for decreasing soil $\mathrm{pH}$. Moreover, $\mathrm{pH}$ of soils in $\mathrm{SW}$ was a little bit higher in comparison to FM condition, which might be due to submergence as occurred by the 2 $5 \mathrm{~cm}$ standing water condition. Another study conducted by Li et al. (2013) and they 
reported that initial soil $\mathrm{pH} 8.27$ reached 7.36 due to $5 \%$ raw rice straw application which is also aggreed with the present findings.

The EC values of the post harvest soils both in the field moist (FM) and $2-5 \mathrm{~cm}$ satnding water (SW) conditions were found to be influenced by different rates of indigenous organic amendments (rice hull and pistia, Fig. 6). The maximum EC values $(3.60 \mathrm{dS} / \mathrm{m}$ in FM and $3.43 \mathrm{dS} / \mathrm{m}$ in $\mathrm{SW}$ ) were recorded for the $\mathrm{T}_{0}$ (control) treatment. It was observed that the increased levels of treatments from $\mathrm{T}_{0}$ to $\mathrm{T}_{3}$, the soil $\mathrm{EC}$ values were decreased and in the treatment $\mathrm{T}_{3}$ to $\mathrm{T}_{5}$, the $\mathrm{EC}$ values were almost stable. But the EC of soils

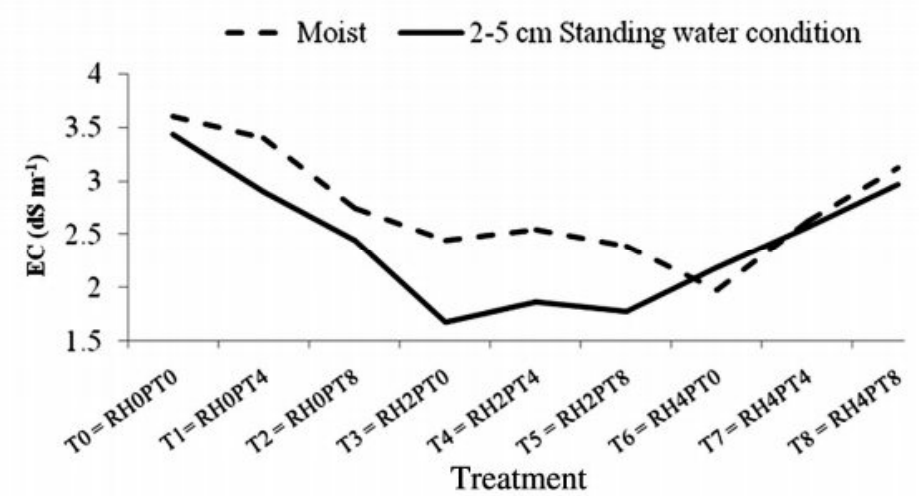

Fig. 6. Effects of rice hull and pistia on the EC values of the post harvest soils under field moist (moisture 70\%) and $2-5 \mathrm{~cm}$ standing water conditions during rice cultivations.

increased gradually from the $T_{5}$ to $T_{6}$ treatments and reached maximum with the higher rates of amendments and their combinations. Another study conducted by Gonzalez et al. (2010) and they achieved a substantially decreased EC of saline-sodic soils with the addition of different organic amendments. The decrease in EC value was the result of organic matter triggered leaching of excessive ions by improving the physical properties of soil. The further increase in EC of soils might be due to presence of salts in organic amendments. The present study is also in accordance with the finding of Gonzalez et al. (2010).

\section{Conclusion}

The findings of the present study demonstrated that the application of rice hull and pistia to the studied saline soil significantly $(\mathrm{p} \leq 0.05)$ increased the vegetative growth of rice variety BRRI Hybrid Dhan-6. Further, plant height, tiller production, fresh shoot and dry shoot matter weights were found to have better responses in the $2-5 \mathrm{~cm}$ standing water 
condition than that of the field moist condition. The soil pHs in standing water condition were a little bit higher in comparison to FM condition, which might be due to the impacts of submergence as happened due to the application of standing water. The findings also suggest further research is needed to carry out for the elevated dose of rice hull and pistia to reduce the adverse effect of salinity in a cost-effective way. On the other hand, moisture variation plays a potential role for the production of rice that suggested for proper irrigation is necessary aimed at the higher production and reclamation of saline soil.

\section{Acknowledgements}

The study was carried out under the project entitled 'Assessment of Impacts of Climate Change on Soil Health and Food Security, and Adaptation of Climate-smart Agriculture in Most Adversely Affected Areas of Bangladesh' funded (2017-'18) by BCCT, MoEFCC, Government of the People's Republic of Bangladesh. They are also grateful to the Ministry of Science and Technology for providing NST fellowships for all authors, except for the second author.

\section{References}

BBS (Bangladesh Bureau of Statistics). 2017. Yearbook of Agricultural Statistics-2016. Planning Division, Ministry of planning, Government of the People's Republic of Bangladesh, Dhaka.

Begum, M. and H.R. Khan. 2013. Influence of gypsum, rice-hull and different levels of saline water irrigation on water soluble cations and organic matter content in different saline soils in response to wheat. International J. Res. Applied Nat. and Social Sci. 1: 15-22.

Black, C.A. (ed.). 1965. Methods of Soil Analysis: Part 2, Series 9, pp. 894-1372, Am Soc. Agron. Inst. Publ., Madison, WI.

BRRI (Bangladesh Rice Research Institute). 2015. Modern Rice Cultivation, $18^{\text {th }}$ Edition.

Chapman, H.D. 1965. Cation exchange capacity, In: Methods of Soil Analysis, Part 2 (ed.) C.A. Black. Agrn. Series 9. pp 891-900, Am. Soc. Agron., Publ. Madison, WI, USA.

Gonzalez, M.E., R. Gomez and R. Comese. 2010. Influence of organic amendments on soil quality potential indicators in an urban horticultural Sys-Tem. Biore-Source Technol. 101: 8897-8901.

Jackson, M.L. 1973. Soil Chemical Analysis. pp. 46-183. Prentice Hall of India Pvt. Ltd., New Delhi.

Kamara, A., H.S. Kamara and M.S. Kamara. 2015. Effect of rice straw biochar on soil quality and the early growth and biomass yield of two rice varieties. Agricultural Sciences 6: 798-806.

Kaniz, F. and M.H.R. Khan. 2013. Reclamation of saline soil using gypsum, rice hull and saw dust in relation to rice production. J. Adv. Sci. Res. 4 (3): 1-5.

Kanwal, S., S. Iram, M. Khan and I. Ahmad. 2011. Aerobic composting of water lettuce for preparation of phosphorus enriched organic manure. African Journal of Microbiology Research 5(14): 1784-1793. 
Khan, M.H.R., M.M.A. Bhuiyan, and S.M. Kabir. 2016. Effects of selected treatments and techniques for the reclamation and improvement of Cheringa acid sulfate soil under rice production in the coastal plain of Cox's bazar. J. Asiat. Soc. Bangladesh, Sci. 42(1): 29-40.

Li, F., X. Cao,L. Zhao, F. Yang, J. Wang and S. Wang. 2013. Short term effects of raw rice straw and its derived biochar on greenhouse gas emission in five typical soils in China. Soil Sci. Plant Nut.59 (5): 800-811.

Nelson, D.W. and L.E. Sommers. 1982. Total carbon, organic carbon and organic matter. In: Methods of Soil Analysis. Patr-2. (2nd Ed.). pp. 539-579. A. L. Page (ed.), American Society of Agronomy Publication, Madison, WI.

Olsen, S.R., C.V. Cale, F.S. Watanabe and L.A. Dean. 1954. Estimation of available phosphorus in soils by extraction with sodium bicarbonate. USDA Circ. 939, Washington, USA.

Parham, J.A., S.P Deng, W.R Roun and G.V. Johnson. 2002. Long-term cattle manure application in soil. Bio. Fertile Soils 35: 328-337.

Piper, C.S. 1966. Soil and Plant Analysis, pp. 77. Hans Publisher. Bombay.

Prakash, N.B., H. Nagaraj, N. Vasuki, R. Siddaramappa and S. Itoh. 2002. Effect of recycling of plant silicon for sustainable rice farming in south India. In: $17^{\text {th }}$ WCSS, August, Thailand, pp. 851(1-7).

Pratt, P.F. 1965. Methods of Soil Analysis (Black C.A. Ed.) pp. 1022. Am. Soc. Agron. Madison, Wisconsin, USA.

Quadir, D.A. and M.A. Iqbal. 2008. Investigation on the Variability of the Tropical Cyclones Impacting the Livelihood of the Coastal Inhabitants of Bangladesh, Consultancy Report, International Union for Conservation of Nature (IUCN) - Bangladesh IUCN Contract No. IUCNB-Consult-069 \& IUCNB-Consult-070.

Reddy, I.N.B.L.,B. Kim, I. Yoon, K. Kim and T. Kwon. 2017. Salt tolerance in rice: Focus on mechanisms and approaches. Rice Science 24(3): 123-144.

Richards, L.A. 1954. Diagnosis and improvement of saline and alkali soils. US Govt. Print. Office, Washington, USA, 1954: In: USDA Hand Book No. 60: 84-156.

Sakai, H. 1978. Some analytical results of sulfur deficient plants, soil, and water, Workshop on sulfur nutrition in rice, December, BRRI, Publication No. 41: 35-59.

SRDI (Soil Resource Development Institute). 2010. Saline Soils of Bangladesh. Ministry of Agriculture, Dhaka, Bangladesh.

USSLS (United States Salinity Laboratory Staff). 1954. Diagnosis and improvement of saline and alkali soils. In: USDA Hand Book No. 60. pp. 84-156. US Govt. Print. Office, Washington, USA. 